\title{
Characterisation of Perovskites in a Calcium Sulfo Aluminate Cement
}

\author{
G. Le Saout ${ }^{1(\bowtie)}$, R. Idir ${ }^{2}$, and J.-C. Roux ${ }^{1}$ \\ ${ }^{1}$ C2MA, IMT Mines Ales, Univ Montpellier, Ales, France \\ gwenn. le-saout@mines-ales.fr \\ 2 CEREMA, DIM Project Team, Provins, France
}

\begin{abstract}
Calcium sulfo aluminate cement $(\mathrm{C} \overline{\mathrm{S}} \mathrm{A})$ is a promising low $\mathrm{CO}_{2}$ footprint alternative to Portland cement. The phase assemblage of a commercial CSA cement was investigated by a combination of XRD, SEM-EDX and selective extraction techniques. This study focused on the composition of perovsite phases present in the cement.
\end{abstract}

Keywords: Calcium sulfo aluminate cement $\cdot$ Perovskite $\cdot$ X-ray diffraction • Scanning electron microscope

\section{Introduction}

Calcium sulfo aluminate cements $(\bar{C} \bar{S} A)^{1}$ were developed by the China Building Material Academy in the seventies. C $\bar{S} A$ have many specific properties compared to Portland cement as fast setting, rapid hardening, shrinkage reduction. This special cement used alone or in combination with calcium sulphates and Portland cement has found applications such as airport runways and roads patching, selfleveling mortars, tile adhesives grouts... (Zhang et al. 1999). This is also a promising low CO2 footprint alternative to Portland cement due to the difference in the amount of energy used to produce $\mathrm{C} \overline{\mathrm{S}} \mathrm{A}$ cements (lower kiln temperatures and energy at the mill to grind). The main raw materials used for making $\mathrm{C} \overline{\mathrm{S}} \mathrm{A}$ cements are bauxite, limestone, clay, and gypsum and this leads to a mineralogical composition very different than Portland cement. While many studies have been carried out on the characterization of Portland cement, few are available concerning $\mathrm{C} \overline{\mathrm{S}} \mathrm{A}$. In this study, we report a characterization of a commercial $C \bar{S} A$ using Rietveld quantitative analysis and scanning electron microscopy.

\footnotetext{
${ }^{1}$ Standard cement chemistry notation is used.

As per this simplified notation: $\mathrm{C}=\mathrm{CaO}, \mathrm{A}=\mathrm{Al}_{2} \mathrm{O}_{3}, \mathrm{~F}=\mathrm{Fe}_{2} \mathrm{O}_{3}, \mathrm{~S}=\mathrm{SiO}_{2}, \mathrm{~S}^{-}=\mathrm{SO}_{3}$ and $\mathrm{T}=\mathrm{TiO}_{2}$. 


\section{Methods and Approaches}

The CS $\bar{S}$ A cement was from a commercial supplier and the chemical characteristics of the cement are given in Table 1 .

Table 1. Mineralogical and chemical compositions of the CSA. Mineralogical composition determined by XRD/Rietveld analysis. Chemical analysis by X-ray fluorescence (DIN 51001)

\begin{tabular}{l|l|l|c}
\hline Minerals & Mass \% & Oxides & Mass \% \\
\hline Anhydrite & 18.3 & $\mathrm{SiO}_{2}$ & 8.42 \\
\hline Gypse & 2.9 & $\mathrm{Al}_{2} \mathrm{O}_{3}$ & 19.1 \\
\hline Ye'elimite & 31.4 & $\mathrm{Fe}_{2} \mathrm{O}_{3}$ & 6.94 \\
\hline Belite & 21.2 & $\mathrm{TiO}_{2}$ & 0.76 \\
\hline Perovskite & 11.3 & $\mathrm{~K}_{2} \mathrm{O}$ & 0.08 \\
\hline Ferrite & 5.4 & $\mathrm{Na}_{2} \mathrm{O}$ & 0.02 \\
\hline Merwinite & 1.9 & $\mathrm{CaO}$ & 44.9 \\
\hline Calcite & 3.5 & $\mathrm{MgO}^{\prime} \mathrm{O}$ & 1.27 \\
\hline Magnesite & 1.5 & $\mathrm{SO}_{3}$ & 15.2 \\
\hline a Loss on ignition measured by \\
calcination until 1025 ${ }^{\circ} \mathrm{C}$ according to \\
ISO 12677
\end{tabular}

In order to analyze mineralogical composition, X-ray diffraction was performed on cement with a diffractometer BRUKER D8 Advance. Powder samples were analyzed using an incident beam angle $(\mathrm{Cu} \mathrm{K} \alpha, \lambda=1.54 \AA)$ varying between 5 and $70^{\circ}$. Software X'Pert High Score was used to process diffraction patterns and crystals were identified using the Powder Diffraction File database. Rietveld analysis allowed obtaining mass fractions of crystalline phases in the cement.

For the microscopical investigations, powder samples were impregnated using a low viscosity epoxy and polished down to $0.25 \mu \mathrm{m}$ using diamond pastes. The samples were further coated with carbon $(\sim 15 \mathrm{~nm})$ and examined using a Quanta 200 FEG scanning electron microscope (SEM) from FEI coupled to an Oxford Xmax N $80 \mathrm{~mm}^{2}$ energy dispersive X-ray spectroscopy (EDX) analyser.

In order to improve the characterization of the cement, two different selective dissolution methods were used. In the first method, the silicate phases were removed in a solution of acid salicylic in methanol (Hjorth and Lauren 1971). In addition, a second selective dissolution method was used to get mainly perovskite phases in C $\overline{\mathrm{S} A}$ by removing ye'elimite, anhydrite, gypsum with $5 \% \mathrm{Na}_{2} \mathrm{CO}_{3}$ solution (Wang 2010). The method was modified to prevent precipitation of $\mathrm{CaCO}_{3}$ by washing the filtered suspension with $6 \%$ acetic acid. The filter paper and contents were placed in an oven at $105{ }^{\circ} \mathrm{C}$ until a constant weight was reached. 


\section{Results and Discussion}

The main phases observed in the experimental diffraction pattern (Fig. 1a) are the orthorhombic ye'elimite $\mathrm{C}_{4} \mathrm{~A}_{3} \overline{\mathrm{S}}$ with small amount of the pseudo cubic form, belite $\beta$ and $\alpha^{\prime}{ }_{\mathrm{H}-} \mathrm{C}_{2} \mathrm{~S}$ and perovskites from the $\mathrm{CS} A$ clinker. Anhydrite II $\mathrm{C} \overline{\mathrm{S}}$ is also present as mineral addition. Perovskite family has crystal structures related to the mineral perovskite CT. Ferrite phase $\mathrm{Ca}_{2}\left(\mathrm{Al}_{\mathrm{x}} \mathrm{Fe}_{1-\mathrm{x}}\right)_{2} \mathrm{O}_{5}$ is usually present in $\mathrm{C} \overline{\mathrm{S}} \mathrm{A}$ and its structure is derived from that of perovskite by the substitution of $\mathrm{Al}$ and $\mathrm{Fe}$ for $\mathrm{Ti}$, together with ordered omission of oxygen atoms, which causes onehalf of the sheets of octahedral in perovskite to be replaced by chains of tetrahedral (Taylor 1997). To obtain a good Rietveld refinement, it is also necessary to add a perovskite phase CT (Alvarez- Pinazo et al. 2012). The titanium dioxide is present by the use of bauxite, which usually contains some $\mathrm{TiO} 2$, as raw materials in the manufacturing process of $\mathrm{C} \overline{\mathrm{S}} \mathrm{A}$ clinker. The peaks associated with this cubic phase are confirmed in the XRD pattern of the $\mathrm{C} \overline{\mathrm{S}} \mathrm{A}$ after the extraction of the main phases (Fig. 1b).

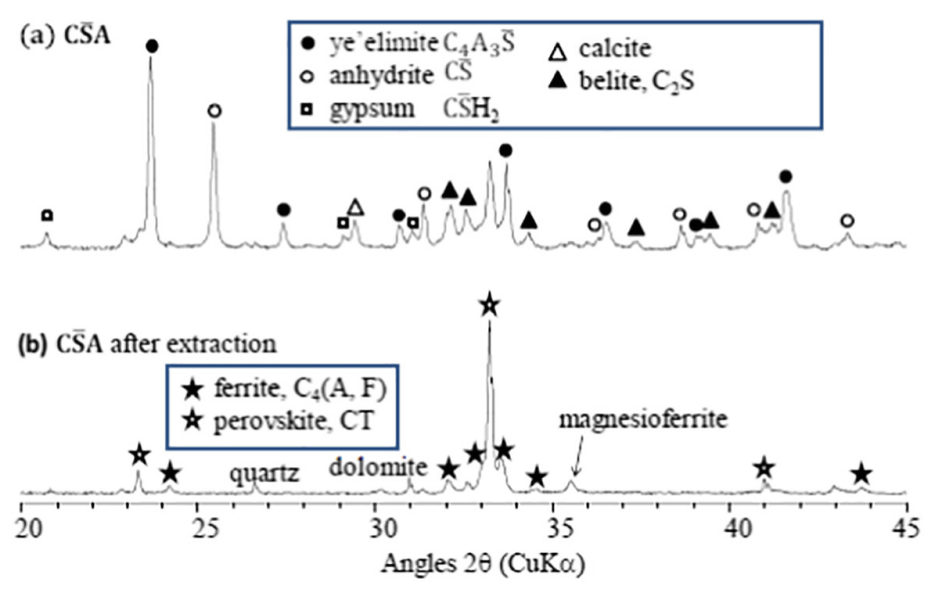

Fig. 1. Diffraction pattern of the cement as received (a), after extraction (b)

However, with the assumed stoichiometry of perovskite CT, the elemental oxide composition $\mathrm{TiO}_{2}$ calculated from phase content deduced by Rietveld analysis is strongly overestimated in comparison with XRF analysis.

EDX analysis on polished section of $\overline{C S A}$ (Fig. 2a) and $\overline{C S} A$ after extraction revealed an average composition of ferrite $\mathrm{Ca}_{1.99} \mathrm{Al}_{0.39} \mathrm{Si}_{0.1} 0 \mathrm{Fe}_{1.35} \mathrm{Ti}_{0.08} \mathrm{Mg}_{0.07} \mathrm{O}_{5.00}$ not far from the brownmillerite series $\mathrm{Ca}_{2}\left(\mathrm{Fe}_{2-\mathrm{x}} \mathrm{Al}_{\mathrm{x}}\right) \mathrm{O}_{5}$. However, the average composition of perovskite $\mathrm{Ca}_{2.00} \mathrm{Al}_{0.30} \mathrm{Si}_{0.22} \mathrm{Fe}_{1.06} \mathrm{Ti}_{0.40} \mathrm{Mg}_{0.05} \mathrm{O}_{5.31}$ is very different to the $\mathrm{Ca}_{2} \mathrm{Ti}_{2} \mathrm{O}_{4}$ composition. These compositions were similar to those observed in the ferrite/perovskite phases of a calcium aluminate cement (Gloter et al. 2000). We also observed in some grains perovskite lamellae with high amount of Ti on the scale of few micrometers (Fig. 2b). 


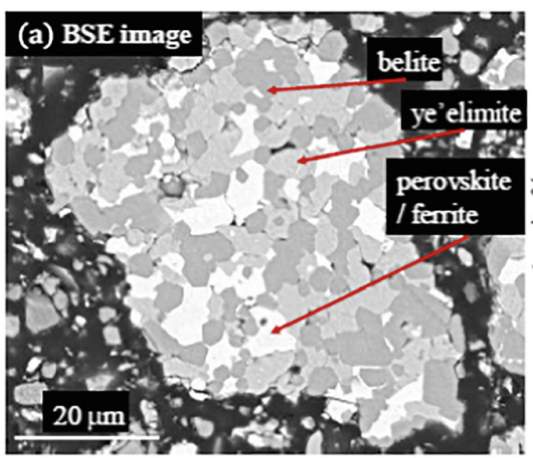

(b) EDX analysis perovskite

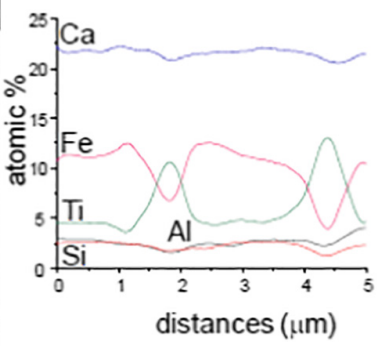

Fig. 2. Back scattering image of the cement (a), example of EDX analysis on perovskite (b)

\section{Conclusions}

The phase assemblage of a commercial calcium sulfo aluminate cement has been investigated with a special attention to the ferrite- perovskite phases. The ferrite composition is closed to the brownmillerite $\mathrm{Ca}_{2}\left(\mathrm{Fe}_{2-\mathrm{x}} \mathrm{Al}_{\mathrm{x}}\right) \mathrm{O}_{5}$ whereas the perovskite shows heterogeneity with important substitution of $\mathrm{Ti}$ by $\mathrm{Fe}, \mathrm{Al}$ and $\mathrm{Si}$.

Acknowledgements. The authors acknowledge A. Diaz (C2MA, IMT Mines Ales) for sample preparation for SEM experiments

\section{References}

Alvarez- Pinazo G, Cuesta A, Garcia-Maté M, Santacruz I, Losilla ER, De la Torre AG, LeonReina L, Aranda MAG (2012) Rietveld quantitative phase analysis of Yeelimitecontaining cements. Cem Concr Res 42:960-971

Gloter A, Ingrin J, Bouchet D, Scrivener K, Colliex C (2000) TEM evidence of perovskitebrownmillerite coexistence in the $\mathrm{Ca}\left(\mathrm{Al}_{\mathrm{x}} \mathrm{Fe}_{1-\mathrm{x}}\right) \mathrm{O}_{2.5}$ system with minor amounts of titanium and silicon. Phys. Chem. Miner 27:504-513

Hjorth L, Lauren K-G (1971) Belite in Portland cement. Cem Concr Res 1:27-40

Taylor HFW (1997) Cement Chemistry. Thomas Telford, London

Wang J (2010) Hydration mechanism of cements based on low- $\mathrm{CO}_{2}$ clinkers containing belite, ye'elimite and calcium alumino ferrite. $\mathrm{PhD}$ dissertation, University of Lille I, France

Zhang L, Su M, Wang Y (1999) Development of the use of sulfo- and ferroaluminate cements in China. Adv Cem Res 11:15-21 
Open Access This chapter is licensed under the terms of the Creative Commons Attribution 4.0 International License (http://creativecommons.org/licenses/by/4.0/), which permits use, sharing, adaptation, distribution and reproduction in any medium or format, as long as you give appropriate credit to the original author(s) and the source, provide a link to the Creative Commons license and indicate if changes were made.

The images or other third party material in this chapter are included in the chapter's Creative Commons license, unless indicated otherwise in a credit line to the material. If material is not included in the chapter's Creative Commons license and your intended use is not permitted by statutory regulation or exceeds the permitted use, you will need to obtain permission directly from the copyright holder.

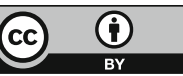

